\title{
PENGARUH MODEL PENGAJARAN INDUKTIF KATA BERGAMBAR TERHADAP KETERAMPILAN MENULIS MAHASISWA PROGRAM STUDI PENDIDIKAN BAHASA JERMAN
}

\author{
Jolanda Tomasouw \\ e-mail: marland_mt@yahoo.co.id \\ Pendidikan Bahasa Jerman FKIP UNPATTI Ambon
}

\begin{abstract}
Abstrak: Model pengajaran induktif kata bergambar merupakan salah satu model pengajaran yang digunakan dalam mengajar Bahasa Jerman pada kelas awal dan model ini diarahkan agar pemelajar dapat menyelesaikan tugas-tugas yang cukup kompleks karena model ini memerlukan tingkat berpikir yang tinggi. Penelitian ini bertujuan mengetahui pengaruh penggunaan model pengajaran induktif bergambar terhadap kemampuan menulis bahasa Jerman mahasiswa. Tipe penelitian yang digunakan adalah eksperimen dengan menggunakan desain kelompok tunggal dengan memberikan pre-test dan post-test. Penelitian ini dilaksanakan di Program Studi Pendidikan Bahasa Jerman Fakultas Keguruan dan Ilmu Pendidikan Universitas Pattimura Ambon dengan sampel mahasiswa Program Studi Bahasa Jerman Semester II tahun ajaran 2013/2014 dengan jumlah responden 15 mahasiswa. Penelitian, yang dilaksanakan Februari-April 2014, menunjukan terdapat pengaruh penggunaan model pengajaran induktif bergambar terhadap kemampuan menulis bahasa Jerman mahasiswa semester II FKIP Unpatti. Hal itu berarti model pengajaran induktif kata bergambar memanfaatkan kemampuan pembelajar untuk berpikir secara induktif dan sangat memotivasi mahasiswa dalam kemampuan menulis. Di samping itu model ini memungkinkan mereka membangun generalisasi yang akan membentuk dasar analisis struktural mereka secara sistematik.
\end{abstract}

Kata kunci : keterampilan menulis, model induktif, kata bergambar.

\section{EFFECT OF WORD PICTURE INDUCTIVE TEACHING MODEL TOWARDS STUDENTS' WRITING SKILL AT GERMANY STUDY PROGRAM.}

\begin{abstract}
Inductive word picture teaching model is an instructional model used for the students at beginner level at the German Study Program to direct them to complete the complicated tasks applying higher thinking order. This research aimed at discovering the effect of this model towards the students' writing skill in German. This experimental research applied single design with pre- and post- tests in Faculty of Teachers Education, Pattimura University, Ambon during the second semester of 2013/2014. The result of research showed, the model has significant influence to writing skill. This means, the model forces the students to think inductively in writing. Besides, the model enables them to construct their basic structural analysis systematically.
\end{abstract}

Keywords : writing skill, inductive model, picture word.

\section{PENDAHULUAN}

Tercapainya hasil belajar yang memadai tentunya tidak terlepas dari suatu proses belajar membelajarkan yang pada intinya merupakan sebuah proses interaksi antar pembelajar dan pemelajar. Interaksi tersebut melibatkan komponen-komponen yang menuntut sebuah tujuan untuk mencapai suatu keterampilan. Dengan demikian, proses belajar membelajarkan akan berlangsung secara optimal dan efektif bila direncanakan dengan baik dan dikelola dengan baik pula. Untuk itu pembelajar harus memerankan perannya secara profesional agar bisa memiliki pengetahuan dan keterampilan, serta bagaimana merencanakan dan mengelola suatu proses belajar membelajarkan dengan baik. Salah satu komponen belajar membelajarkan yang paling utama dan menjadi kunci keefektifan pengajaran adalah penggunaan model pengajaran. Dengan menggunakan model pengajaran yang tepat akan memberikan dampak yang baik bagi peningkatan kemampuan menulis mahasiswa bahasa Jerman.

Tetapi pada kenyataan jauh dari apa yang diharapkan dan hal itu tergambar dari hasil tes 
mahasiswa. Banyak indikator yang berpengaruh, antara lain lemahnya motivasi belajar, penguasaan kosa kata yang sangat minim, maupun penggunaan model ataupun strategi membelajarkan yang kurang baik. Oleh karena itu, dibutuhkan suatu model pengajaran yang bisa memotivasi pembelajar sehingga tujuan yang diharapkan dapat tercapai. Salah satu model pengajaran yang dapat menjawab tantangan tersebut di atas adalah model induktif kata bergambar (picture word inductive model) yang merupakan pengembangan dari model memproses informasi (information-processing model). Model induktif kata bergambar ini adalah memadukan model berpikir induktif dengan model penemuan konsep. Tujuannya adalah agar pemelajar dapat belajar kata, kalimat, dan paragraf dari sebuah gambar. Model pengajaran ini dirasakan sangat baik karena dapat memotivasikan pembelajar melalui gambar-gambar yang menarik sehingga hal tersebut dapat membangun skemata mereka.

Berdasarkan uraian di atas maka yang menjadi permasalahan dalam penelitian ini adalah "Apakah Terdapat Pengaruh Penggunaan Model Pengajaran Picture Word Inductive terhadap keterampilan menulis mahasiswa program studi Bahasa Jerman?“ Untuk mendukung penelitian ini, landasan teoretis yang digunakan meliputi: (a) hakekat keterampilan menulis, (b) hakekat model pengajaran, (c) model pengajaran induktif kata bergambar, dan (d) media pengajaran visual.

\section{Hakekat Keterampilan Menulis}

Menulis adalah suatu keterampilan berbahasa yang diperoleh melalui latihan, dipakai sebagai alat untuk mengungkapkan pikiran dan perasaan, bersifat reproduktif atau produktif dan ekspresif untuk dikomunikasikan kepada orang lain (Nangoi, 1993:9). Menulis merupakan suatu kegiatan memproduksi bahasa seperti berbicara (Glück 1988:28). Kemampuan berbahasa secara produktif berarti bahwa pemelajar mempunyai kemampuan menghasilkan ungkapanungkapan baru secara mandiri dalam bentuk lisan maupun tulisan berdasarkan materi-materi yang telah dipelajari (Hardjono 1988:86).

Dalam menghasilkan suatu tulisan yang produktif tentu membutuhkan suatu proses.Oleh sebab itu, proses menulis dapat dilakukan melalui tiga tahap. Pertama, persiapan. Dalam tahap ini topik ditentukan, ide-ide dikumpulkan dan lebih difokuskan pada materi yang akan dikembangkan. Kedua, penulisan. Dalam tahap ini ide-ide ditulis dan dikembangkan. Ketiga, revisi. Dalam tahap ini wacana yang sudah ditulis disempurnakan mulai dari kata- kata, kalimat-kalimat sampai pada teks sekalipun akan diperiksa kembali dan disempurnakan sesuai dengan tema yang dibahas (Cooper, 1988:165).

\section{Hakekat Model Pembelajaran}

Model-model pengajaran pada dasarnya dapat membantu pembelajar untuk memperoleh informasi, gagasan, kompetensi, nilai, cara berpikir, dan untuk mengekspresikan diri mereka sendiri (Joyce dkk., 1992:1). Pemelajar sebenarnya sedang membelajarkan untuk bagaimana mereka belajar. Pada hakikatnya, hasil pengajaran jangka panjang yang paling penting adalah bagaimana siswa mampu meningkatkan belajarnya dengan lebih mudah dan lebih efektif pada masa yang akan datang.

Istilah model pengajaran memiliki karakteristik yang sama dengan istilah strategi pengajaran, metode pengajaran, atau prinsip pengajaran. Akan tetapi, model pengajaran memiliki dua keistimewaan. Pertama, konsep model menyiratkan sesuatu yang lebih besar daripada strategi, metode, atau teknik tertentu. Istilah model pengajaran mencakup pendekatan pengajaran secara keseluruhan dan bukan strategi atau teknik tertentu. Model-model pengajaran memiliki beberapa atribut yang tidak dimiliki berbagai strategi dan metode spesifik. Atribut -atribut tersebut adalah adanya basis teoretis yang koheren atau sebuah sudut pandang tentang apa yang seharusnya dipelajari dan bagaimana siswa mempelajarinya. Kedua, konsep model pengajaran berfungsi sebagai alat komunikasi yang penting bagi guru (Arends, 2008: 259-260).

Model pengajaran merupakan suatu perencanaan atau suatu pola yang digunakan sebagai pedoman dalam merencanakan pengajaran di kelas atau pengajaran dalam tutorial dan untuk menentukan perangkat-perangkat pengajaran termasuk di dalamnya buku-buku, film, komputer, kurikulum, dan lain-lain . Setiap model pengajaran mengarahkan pemelajar untuk mendesain pengajaran yang dapat membantu peserta didik sedemikian rupa sehingga tujuan pengajaran tercapai (Joice, 1992 : 4).

Model pengajaran juga diartikan sebagai kerangka konseptual yang melukiskan prosedur yang sistematis dalam mengorganisasikan pengalaman belajar untuk mencapai tujuan belajar tertentu, dan berfungsi sebagai pedoman bagi para perancang pengajaran dan para pembelajar dalam merencanakan aktivitas belajar membelajarkan (Soekamto, 1993:64). Dalam membelajarkan suatu pokok bahasan (materi) tertentu harus dipilih model pengajaran yang paling sesuai dengan tujuan yang akan dicapai (Trianto, 2007:9). Oleh karena itu, dalam memilih suatu model pengajaran diperlukan pertimbangan- 
pertimbangan khusus, misalnya materi pelajaran, tingkat perkembangan kognitif siswa, dan sarana atau fasilitas yang tersedia, sehingga tujuan pengajaran yang telah ditetapkan dapat tercapai.

Dengan demikian, merupakan hal yang sangat penting bagi para pembelajar untuk mempelajari dan menambah wawasan tentang model pengajaran yang telah diketahui. Dengan menguasai beberapa model pengajaran, maka seorang pemelajar akan merasakan adanya kemudahan di dalam pelaksanaan pengajaran di kelas, sehingga tujuan pengajaran apat tercapai dan tuntas sesuai yang diharapkan.

\section{Model Pengajaran Induktif Kata Bergambar.}

Model pengajaran induktif merupakan model pengajaran yang bersifat langsung tapi sangat efektif untuk membantu pemelajar mengembangkan keterampilan berpikir tingkat tinggi dalam kaitannya dengan proses pembelajaran. Model berpikir induktif cenderung lebih mudah digunakan pada materi pengajaran yang masih bersifat konseptual. Hal ini dapat dilihat pada pola dan karakteristik pengajaranyang merupakan kategori berpikir induktif ini. Namun, tidak menutup kemungkinan aktivitas yang dikembangkan dalam proses pengajaran akan melibatkan unsur psikomotorik dari peserta didik. Model berpikir induktif meyakini bahwa siswa sebagai peserta didik merupakan konseptor ilmiah. Setiap saat seseorang selalu berusaha untuk melakukan suatu konseptualisasi dalam hal apapun, proses berpikir induktif diperlukan (Bruce Joyce, Marsha Weil dan Emiy Calhoun, 2009:114).

Fokus merupakan karakteristik utama dalam model berpikir induktif. Fokus membantu peserta didik untuk berkonsentrasi pada satu ranah/ kemampuan berpikir yang dapat mereka kuasai, tanpa mengecilkan keinginan dalam hati mereka yang jelas membuatnya tidak bisa menggunakan seluruh kemampuan untuk menghasilkan suatu gagasan yang luar biasa. Hal utama yang perlu dilakukan adalah menyajikan seperangkat data yang menyediakan informasi terhadap suatu cakupan mata pelajaran tertentu dengan meminta peserta didik mempelajari sifat-sifat objek dalam perangkat yang disajikan tersebut.

Model berpikir induktif dapat membantu peserta didik untuk mengumpulkan informasi dan mengujinya secara ilmiah (dengan tahap perkembangan usia dan berpikir peserta didik) dengan teliti, mengolah informasi ke dalam konsepkonsep, dan belajar memanipulasi konsep-konsep tersebut. Apabila digunakan secara bertahap, model berpikir induktif juga dapat meningkatkan kemampuan peserta didik untuk membentuk konsepkonsep secara efisien dan meningkatkan jangkaian perspektif dari sisi mana mereka memandang suatu informasi tertentu. Salah satu bagian dari model pengajaranberpikir induktif yang dirasakan sangat baik untuk pengajaranbaca tulis dalam bahasa Jerman adalah model pengajaraninduktif kata bergambar.

Meskipun ada banyak model pengajaran memiliki sejarah panjang yang terus dikembangkan oleh para penggagasnya, hanya ada segenggaman model-model baru yang hebat yang dianggap perlu dimasukkan ke dalam Models of Teaching. Model induktif kata bergambar (picture-word inductive model) merupakan salah satu strategi pengajaran tambahan yang sangat menarik dan luar biasa, utamanya dalam hal keluasaan landasan dan penerapannya.

Inti merupakan sifat/tujuan belajar siswa saat mereka berusaha mengonstruksikan pengetahuan tentang bahasa (analisis fonetik dan struktural) dan mengembangkan ketrampilan memperluas dan mengelola informasi dalam semua bidang kurikulum. Dalam beberapa hal, strategi ini mungkin merupakan salah satu model konstruksionis terakhir karena baca tulis umum merupakan dasar dimana bidang baca tulis yang sesuai dengan kurikulum dikembangkan.

Model pengajaran induktif kata bergambar (Picture Word Inductif Model = PWIM) menyajikan sebuah model pengajaran yang memusatkan pada otak manusia untuk aktif berpikir melalui data-data yang diterimanya. Pengumpulan data-data yang bersifat khusus akan diproses dan ditarik kesimpulan secara umum. Secara tidak langsung, siswa dilatih untuk mandiri dan konsisten terhadap permasalahan yang dihadapi dengan mengambil kesimpulan yang lebih obyetif dari data yang telah diproses. Model induktif kata bergambar adalah penyelidikan berorientasi strategi seni bahasa yang menggunakan gambar yang berisi benda-benda asing dan tindakan untuk memperoleh kata-kata dari mendengarkan anak-anak dan berbicara kosakata.

Model pengajaran induktif kata bergambar bertujuan antara lain: (1) membangun pandangan kosakata sebagai dasar untuk membaca, belajar mengucapkan dan generalisasi ejaan; (2) memperoleh rasa percaya pada kemampuan seseorang untuk belajar; (3) belajar bagaimana menyelidiki bahasa dan menggunakan pengetahuan dan keterampilan untuk membaca, menulis dan berpartisipasi penuh dalam pendidikan. Model induktif kata bergambar dapat digunakan untuk membelajarkan pengucapan dan mengeja, baik induktif dan eksplisit. Namun, model ini dirancang untuk memanfaatkan kemampuan 
anak untuk berpikir secara induktif. Di samping itu, model induktif kata bergambar ini memungkinkan mereka untuk membangun generalisasi yang membentuk dasar struktural dan analisis fonetik, dan menghormati kemampuan mereka untuk berpikir. Dengan demikian, prinsip utama dari model ini adalah bahwa siswa memiliki kemampuan untuk membuat generalisasi yang dapat membantu mereka untuk menguasai konvensi bahasa.

Langkah-langkah model induktif kata bergambar meliputi: Pertama, memilih gambar yang sesuai dengan tema contohnya tema "Essen und Trinken". Kedua, pemelajar diminta mengenali apa yang dihat dalam gambar, "Essen und Trinken". Ketiga, tandai bagian gambar yang diidentifikasi. Gambar garis dari objek atau daerah yang diidentifikasi, mengucapkan kata, menulis kata, dan lain-lain. Keempat, membaca dan meninjau gambar kata dengan suara keras. Kelima, meminta pemelajar untuk membaca kata-kata (menggunakan garis-garis pada grafik jika perlu) dan untuk mengklasifikasikan kata-kata ke dalam berbagai kelompok, serta membaca dan meninjau grafik gambar kata (mengucapkan kata, mengejanya, mengatakannya lagi). Keenam, menambahkan katakata pendukung untuk memperjelas tema. Ketujuh, mengarahkan pemelajar untuk menciptakan sebuah judul untuk bagan kata gambar. Mintalah pemelajar memikirkan mengenai informasi tentang apa yang ingin mereka katakan tentang hal itu. Kedelapan, pemelajar untuk sebuah kalimat, kalimat, atau paragraf tentang bagan kata gambar. Mintalah pemelajar untuk mengklasifikasikan kalimat, model yang menempatkan kalimat menjadi paragraf yang baik. Kesembilan, membaca dan meninjau kalimat dan paragraf. Diharapkan model ini dapat memberikan sumbangsih yang besar untuk pengembangan pengajaranbahasa asing kedepan.

\section{d. Media PengajaranVisual}

Media adalah berbagai jenis komponen dalam lingkungan siswa yang dapat merangsangnya untuk belajar dan juga merupakan segala alat fisik yang dapat menyajikan pesan serta merangsang siswa untuk belajar. Media pendidikan merupakan salah satu sumber belajar yang dapat menyalurkan pesan sehingga membantu mengatasi hal tersebut (Sadiman, dkk, 2009: 6). Perbedaan gaya belajar, minat, intelegensi, keterbatasan daya indera cacat tubuh atau hambatan jarak geografis, jarak waktu dan lain-lain dapat dibantu diatasi dengan pemanfaatan media pendidikan.

Media pengajaran dapat memenuhi tiga fungsi utama apabila media itu digunakan untuk perorangan, kelompok, atau kelompok pendengar yang besar jumlahnya, yaitu (1) memotivasi minat atau tindakan, (2) menyajikan informasi, dan (3) memberi instruksi (Kemp \& Dayton dalam Arsyad 2010: 19). Untuk memenuhi fungsi motivasi, media pengajarandapat direalisasikan dengan teknik drama atau hiburan. Hasil yang diharapkan adalah melahirkan minat dan merangsang para siswa atau pendengar untuk bertindak (turut memikul tanggung jawab, melayani secara sukarela, atau memberikan sumbangan material). Pencapaian tujuan ini akan mempengaruhi sikap, nilai, dan emosi.

Untuk tujuan informasi, media pengajaran dapat digunakan dalam rangka penyajian informasi di hadapan sekelompok siswa. Isi dan bentuk penyajian bersifat amat umum, berfungsi sebagai pengantar, ringkasan laporan, atau pengetahuan latar belakang. Penyajian dapat pula berbentuk hiburan, drama, atau teknik motivasi. Ketika mendengar atau menonton bahan informasi, para siswa bersifat pasif. Partisipasi yang diharapkan dari siswa hanya terbatas pada persetujuan atau ketidaksetujuan mereka secara mental, atau terbatas pada perasaan tidak/kurang senang, netral, atau senang. Media berfungsi untuk tujuan intruksi di mana informasi yang terdapat dalam media itu harus melibatkan siswa baik dalam benak ataupun mental maupun dalam bentuk aktivitas yang nyata sehingga pembelajaran dapat terjadi. Materi harus dirancang secara lebih sistematis dan psikologis dilihat dari segi prinsip-prinsip belajar agar dapat menyiapkan intruksi yang efektif. Di samping menyenangkan, media pembelajaran harus dapat memberikan pengalaman yang menyenangkan dan memenuhi kebutuhan perorangan siswa.

Belajar merupakan proses peserta didik membangun gagasan/ pemahaman sendiri, maka kegiatan pengajaran hendaknya mampu memberikan kesempatan seluas-luasnya kepada peserta didik untuk berbuat, berpikir, berinteraksi sendiri secara lancar dan termotivasi tanpa hambatan pembelajar (Yamin, 2011 : 97). Suasana belajar yang disediakan pemelajar hendaknya memberikan peluang kepada peserta didik untuk melibatkan mental secara aktif melalui beragam kegiatan, seperti kegiatan mengamati, bertanya/mempertanyakan, menjelaskan, berkomentar, mengajukan hipotesis, mengumpulkan data, dan sejumlah kegiatan mental lainnya. Pemelajar hendaknya tidak memberikan bantuan secara dini dan hendaknya selalu menghargai usaha peserta didik meskipun hasilnya belum sempurna.

Pengajaran merupakan upaya sengaja dan bertujuan yang berfokus kepada kepentingan, 
karakteristik, dan kondisi orang lain agar peserta didik dapat belajar dengan efektif dan efisien (Thobrani \& Mustofa, 2011: 41). Istilah ini merupakan paradigma baru yang menekankan pada prinsip keragaman peserta didik atau pemelajar (learner), dan menggantikan istilah pengajaran atau membelajarkan yang menekankan prinsip keseragaman. Istilah pengajaran lebih banyak berarti sebagai upaya penyampaian informasi kepada pihak lain. Latar belakang teoritisnya didasarkan pada teori psikologi behavioristik dan teori komunikasi searah. Sedangkan, konsep pengajaran didasarkan pada teori psikologi kontruktivistik dan teori komunikasi konvergensi. Konsep pengajaran ini merupakan inti pada lapis pengalaman belajar, yaitu tempat peserta didik membangun diri sendiri berdasarkan pengetahuan dan pengalaman yang diperolehnya melalui interaksi dengan lingkungannya.

Perkembangan kognitif seorang siswa melalui suatu proses asimilasi dan akomodasi (Piaget dalam Thobrani \& Mustofa, 2011:97). Di dalam pikiran seseorang, sudah terdapat struktur kognitif atau kerangka kognitif yang disebut skema. Setiap orang akan selalu berusaha untuk mencari suatu keseimbangan, kesesuaian, atau ekuilibrium antara apa yang baru dialami (pengalaman barunya) dan apa yang ada pada struktur kognitifnya. Jika pengalaman barunya adalah cocok atau sesuai dengan yang tersimpan pada kerangka kognitifnya tidak sesuai atau tidak cocok dengan pengalaman barunya, ketidakseimbangan akan terjadi, dan anak akan berusaha untuk menyeimbangkannya lagi. oleh karena itu, diperlukan proses akomodasi. Dengan demikian dapat disimpulkan bahwa asimilasi adalah suatu proses tempat informasi atau pengalaman yang baru menyatukan diri ke dalam kerangka kognitif yang ada, sedangkan akomodasi adalah suatu proses perubahan atau pengembangan kerangka kognitif yang ada agar sesuai dengan pengalaman baru yang dialaminya.

Sejalan dengan pendapat di atas Arsyad (2010: 15) bahwa dalam suatu proses belajar membelajarkan, dua unsur yang amat penting adalah metode membelajarkan dan media pembelajaran. Kedua aspek ini saling berkaitan. Pemilihan salah satu metode membelajarkan tertentu akan berpengaruh pada jenis media pengajaran yang sesuai, meskipun masih ada berbagai aspek lain yang harus diperhatikan dalam memilih media antara lain, tujuan pembelajaran, jenis tugas dan respons yang diharapkan siswa kuasai setelah pengajaran berlangsung. Pemakaian media pengajaran dalam proses belajar membelajarkan dapat membangkitkan keinginan dan minat yang baru, membangkitkan motivasi dan rangsangan kegiatan belajar (Hamalik, 1986). Penggunaan media pengajaranpada tahap orientasi pengajaranakan sangat membantu keefektifan proses pengajarandan penyampaian pesan dan isi sehingga dapat meningkatkan pemahaman serta mampu menyajikan data dengan menarik dan memadatkan informasi.

Sebagaimana telah dijelaskan sebelumnya bahwa penelitian ini menggunakan model pengajaran induktif kata bergambar. Model ini sangat berkaitan dengan media visual. Oleh sebab itu, media berbasis visual memegang peranan penting dalam proses belajar (Arsyad, 2010:91). Media visual dapat memperlancar pemahaman dan memperkuat ingatan. Bentuk visual bisa berupa gambar/foto, lukisan, diagram maupun peta karena visual dapat menumbuhkan minat pembelajar dan dapat memberikan hubungan antara isi materi pengajaran dengan dunia nyata.

Model pengajaran yang menggunakan visual merupakan salah satu gaya belajar. Gaya pengajaran yang menonjol dalam situasi ruang kelas formal yakni kecondongan pemelajar pada masukan visual, auditoris dan kinestesis (Brown, 2007:138). Pemelajar visual cenderung menyukai tabel, gambar, dan informasi grafis. Pemelajar auditoris lebih senang mendengar ajaran dan audio tape. Pemelajar kinestetis akan memperlihatkan kesukaan pada demonstrasi dan aktivitas fisik yang melibatkan pergerakan tubuh. Pemelajar yang paling berhasil adalah mereka yang memafaatkan masukan visual maupun auditoris, namun sedikit ketekunan akan membedakan pembelajar yang satu dengan yang lainnya. Dengan mengetahui gaya-gaya pengajaranmendorong pembelajar untuk lebih peka untuk membantu pembelajar dalam proses belajar mereka sehingga tujuan pengajaran dapat tercapai.

\section{METODE PENELITIAN}

Peneltian ini bertujuan untuk mengetahui apakah terdapat pengaruh model pengajaran picture word inductive terhadap keterampilan menulis mahasiswa Program Studi Pendidikan Bahasa Jerman. Tipe penelitian yang digunakan adalah eksperimen yang menggunakan desain kelompok tunggal dengan memberikan pre-test dan post-test. Penelitian ini dilaksanakan di Program Studi Pendidikan Bahasa Jerman Fakultas Keguruan dan Ilmu Pendidikan Universitas Pattimura Ambon dengan sampel adalah mahasiswa Program Studi Bahasa Jerman Semester II tahun ajaran 2013/2014 dengan jumlah responden 15 mahasiswa. Waktu penelitian adalah FebruariApril 2014. Variabel penelitian terdiri dari variabel 
bebas, yaitu model induktif kata bergambar dan variabel terikat, yaitu keterampilan menulis. Teknik pengumpulan adalah melalui tes tertulis.

Langkah-langkah dalam penelitian ini, yaitu (a) menyiapkan materi ajar: gambar beserta soal pemandu dan alat bantu mengajar; (b) dosen memberikan gambar sesuai dengan tema pengajaran; (c) mahasiswa memilih gambar berdasarkan tema; (d) mahasiswa mengidentifikasi apa saja yang mereka lihat dari gambar dan mulai menulis kata-kata berdasarkan gambar dalam bentuk asosiogram; (e) mahasiswa menulis kalimat atau teks berdasarkan gambar tersebut; (f) mahasiswa membaca hasil kerja; (g) dosen meninjau hasil kerja; (h) dosen membuat kesimpulan bersama; dan (i) penutup.

\section{HASIL DAN PEMBAHASAN}

Data dari hasil pre-test dan post-test, yang diolah dengan menggunakan uji t-dependent untuk membuktikan hipotesis menunjukan adanya perbedaan yang signifikan antara hasil tes sebelum dan sesudah perlakuan. Hasil pre-test dan post-test secara lengkap tersaji pada tabel 1 dan gambar 1 .

Tabel 1. Hasil Tes Sebelum dan Sesudah Menggunakan Model Pembelajaran Picture Word Inductive Model

\begin{tabular}{|c|c|c|c|c|c|}
\hline No & Subjek & $\mathbf{x 1}$ & $\mathrm{x} 2$ & D & d2 \\
\hline 1. & $\mathrm{~A}$ & 72 & 100 & 28 & 784 \\
\hline 2. & $\mathrm{~B}$ & 12 & 64 & 52 & 2704 \\
\hline 3. & $\mathrm{C}$ & 68 & 100 & 32 & 1024 \\
\hline 4. & $\mathrm{D}$ & 64 & 76 & 12 & 144 \\
\hline 5. & $\bar{E}$ & 32 & 72 & 40 & 1600 \\
\hline 6. & $\mathrm{~F}$ & 48 & 72 & 24 & 576 \\
\hline 7. & $\mathrm{G}$ & 72 & 76 & 4 & 16 \\
\hline 8. & $\mathrm{H}$ & 68 & 72 & 4 & 16 \\
\hline 9. & I & 64 & 70 & 6 & 36 \\
\hline 10. & $\bar{J}$ & 56 & 64 & 8 & 64 \\
\hline 11. & $\mathrm{~K}$ & 56 & 72 & 16 & 256 \\
\hline 12. & $\mathrm{~L}$ & 44 & 64 & 20 & 400 \\
\hline 13. & $\mathrm{M}$ & 56 & 88 & 32 & 1024 \\
\hline 14. & $\mathrm{~N}$ & 36 & 64 & 28 & 784 \\
\hline 15. & $\mathrm{O}$ & 24 & 56 & 32 & 1024 \\
\hline \multicolumn{2}{|r|}{$\mathrm{N}=15$} & $\sum x 1=772$ & $\begin{array}{c}\sum \times 2= \\
1110\end{array}$ & $\sum \mathrm{d}=338$ & $\begin{array}{l}\sum \mathrm{d} 2= \\
10452\end{array}$ \\
\hline
\end{tabular}

Keterangan :
$\sum \times 1=$ Jumlah keseluruhan nilai Pre-test
$\sum \times 2=$ Jumlah keseluruhan nilai Post-test
$\sum \mathrm{d}=$ Jumlah keseluruhan perbedaan nilai

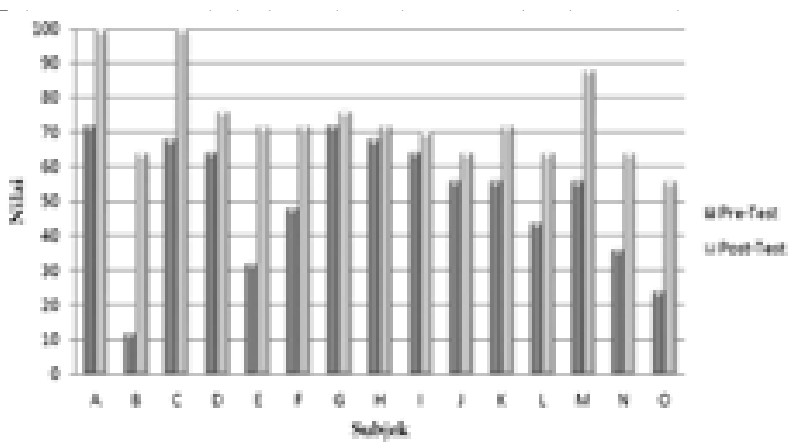

Gambar 1. Grafik perbandingan nilai pre dan post test

Data di atas menunjukkan bahwa secara garis besar terdapat perbedaan yang cukup signifikan antara nilai hasil pre dan post-test meskipun ada beberapa responden yang peningkatannya tidak terlalu banyak. Tetapi ada juga yang peningkatannya sangat menonjol hal ini disebabkan karena perlakuan yang diberikan oleh peneliti kepada pembelajar sangat baik sekali.

Berdasarkan data yang telah dipaparkan, diperoleh nilai $t_{\text {hitung }}=13,57$. Jika dibandingkan dengan $t_{\text {tabel }}$ pada taraf signifikan $=0,05$ dan derajat kebebasan $(\mathrm{db})=14$, maka diperoleh $\mathrm{t}_{\text {tabel }}=2,14$. Dengan demikian, diperoleh nilai $t_{\text {hitung }}(13,57)>t_{\text {tabel }}(2,14)$. Dari tersebut menunjukkan bahwa ada perbedaan nilai keterampilan menulis mahasiswa sebelum dan setelah mahasiswa mendapat perlakuan dengan menerapkan model Picture Word Inductive Model

Dengan demikian, model pengajaran induktif kata bergambar secara efektif dapat membantu mahasiswa untuk berpikir secara induktif tentang gambar yang disajikan tersebut dan kemudian dapat lebih dengan mudah menulis kata-kata, sampai pada teks berdasarkan gambar dengan tepat. Selain itu, dengan menggunakan model pengajaran Induktif Kata Bergambar mahasiswa lebih termotivasi dalam belajar, tidak bosan dan mahasiswa lebih aktif dan kreatif dalam proses belajar. Karena pengajaran ini menggunakan model induktif kata bergambar yang menyajikan cara belajar yang kreatif dan inovatif.

\section{PENUTUP}

\section{Kesimpulan}

Berdasarkan hasil analisis dan pembahasan dapat disimpulkan sebagai berikut: Ada pengaruh penerapan model pengajaran Induktif Kata Bergambar terhadap keterampilan menulis mahasiswa program studi Pendidikan Bahasa Jerman Universitas Pattimura. Hal ini dibuktikan dari hasil perhitungan uji $\mathrm{t}$-dependent skor pre-test dan post-test yang menunjukan bahwa thitung lebih besar dari ttabel $\left(t_{\text {hitung }}=13,57>\right.$ $\left.t_{\text {tabel }}=2,14\right)$. 
Model Induktif Kata Bergambar mempunyai keunggulan sebagai berikut melalui model ini : mahasiswa dapat mengenal berbagai kosa kata dengan cepat melalui gambar di samping itu mereka mampu berpikir secara induktif dimana mahasiswa dapat mengklasifikasikan kata secara umum ke khusus maupun sebaliknya.

Model induktif kata bergambar merupakan salah satu model pengajaran yang mengajarkan cara berpikir yang lebih terkonsep. Mahasiswa diajarkan untuk dapat memproses informasi, mengkaji, dan memberikan hipotesis. Pada model pengajaran ini pengajar berperan sebagai inisiator dan pengawas semua kegiatan dalam kegiatan ini mahasiswa juga harus aktif dalam mencari informasi yang dibutuhkan. Dengan kata lain mahasiswa berusaha menggali potensi yang ada pada dirinya dan belajar untuk menyelesaikan permasalahan.

Dengan demikian, model pengajaran Induktif Kata Bergambar secara efektif dapat membantu mahasiswa dalam menulis teks dengan baik dan benar berdasarkan gambar dan asosiogram yang tersedia, dan juga melalui gambar dapat membangun cara berpikir mahasiswa secara induktif.

\section{Saran}

Berdasarkan kesimpulan diatas maka dapat disarankan beberapa hal antara lain: (1) pengajar dapat menggunakan model induktif kata bergambar dalam proses belajar mengajar bahasa asing khusunya bahasa Jerman dan (2) model induktif kata bergambar merupakan salah satu model pengajarankarena dapat meningkatkan motivasi belajar oleh karena itu model ini dapat diteliti untuk unit analisis lainnya dengan sampel yang lebih luas.

\section{DAFTAR PUSTAKA}

Arends, R.I. (2008). Learning to teach: Buku satu. (Helly Prajitno S. \& Sri Mulyanti, penterjemah). Yogyakarta: Pustaka Pelajar.

Arsyad, A. (1996). Media pembelajaran. Jakarta: PT. Raja
Grafindo Persada

Brown, H.D. (2008). Prinsip pembelajaran dan pengajaran bahasa. (Noor Cholis dan Yusi A. Pareanom, penterjemah). Yogyakarta: Pustaka Pelajar.

Cooper, T. C. (1988). Schreiben als prozez, oder zurück zur natur in der didaktik des schreibens im daf unterricht. In maria lieber und jürgen posset (herausgeber) texte schreiben im germanistik studium. München : Iudicium Verlag.

Hardjono, S. (1988). Prinsip-prinsip pengajaran bahasa dan sastra. Jakarta: P2LPTK Dirjen Pendidikan Tinggi Depdikbud .

Helmut. G, (1988). Schreiben in der fremdsprache deutsch. Eine einführung in maria lieber und jürgen posset (herausgeber) texte schreiben im germanistik studium. München : Iudicium Verlag.

Joyce, B., Weil, M., \& Showers, B. (1992). Models of teaching (fourth edition). Boston: Allyn and Bacon.

Joyce, B., Weil, M., \& Calhoun, E. (2009). Models of teaching (edisi kedelapan) (Achmad Fawaid \& Ateilla Mirza, penterjemah). Yogyakarta: Pustaka Pelajar.

Nangoi, D. (1993). Pengaruh teknikpengajaran berdasarkan metode integratif dan kemampuan awal terhadap hasil belajar menulis. (Disertasi). Jakarta; PPs IKIP Jakarta

Sadiman dkk., (2009). Media pendidikan: Pengertian, pengembangan dan pemanfaataanya. Jakarta : PT Raja Grafindo Persada

Soekamto, T. (1993). Perancangan dan pengembangan sistem instruksional. Jakarta : Intermedia

Thobroni, M.,\& Arif, M. (2011). Belajar E pembelajaran pengembangan wacana dan praktik pembelajaran dalam pembangunan nasional. Jogjakarta : ArRuzz Media.

Trianto. (2007). Model-model pembelajaran inovatif berorientasi konstruktivisme, Jakarta : Prestasi Pustaka

Yamin, M. (2011). Paradigma baru dalam pembelajaran. Jakarta : Gaung Persada. 